\title{
Türkiye'de Petrol Fiyatları ve Hisse Senedi Fiyatları Arasındaki Nedensellik İlişkisi: Boostrap Rolling Window Yaklaşımı ${ }^{1}$
}

\author{
The Causal Relationship Between Oil Prices and Stocks Prices in Turkey: \\ Boostrap Rolling Window Approach

\section{Günay ÖZCAN² a \\ Çiğdem KARTER ${ }^{3}$}

\author{
2 Necmettin Erbakan Üniversitesi, Siyasal Bilgiler Fakültesi gny_akel@hotmail.com Orcid ID: 0000-0002-1950-4255 \\ ${ }^{3}$ Bağımsız Araştırmacı cigdemkarter22@gmail.com Orcid ID: 0000-0002-1285-5394 \\ aYazışılan yazar/Corresponding author

$\begin{array}{ll}\text { Makale Bilgisi: } & \text { Araştırma Makalesi } \\ \text { Geliş Tarihi: } & 20.11 .2020 \\ \text { DüzeltmeTarihi: } & 23.11 .2020 \\ \text { Kabul Tarihi: } & 21.12 .2020\end{array}$

$\begin{array}{ll}\text { Article Info: } & \text { Research Article } \\ \text { Date Submitted: } & 20.11 .2020 \\ \text { Date Revised: } & 23.11 .2020 \\ \text { Date Accepted: } & 21.12 .2020\end{array}$

\section{Özet}

Hisse senedi fiyatların etkileyen birçok makroekonomik değişken bulunmaktadır. Bu değişkenlerden biri de petrol fiyatlarıdır. Petrol fiyatları sadece ülke ekonomileri ve reel piyasalar üzerinde etken değil; ülkelerin finansal piyasaları ve bu piyasalarda işlem gören hisse senedi fiyatları üzerinde de etkendir. Bu doğrultuda petrol fiyatlar ile hisse senedi fiyatları arasındaki ilişkinin incelenmesi, bu faktörler arasındaki bă̆ıntının daha iyi anlaşılmasına olumlu katkı yapacaktır.

Bu çalışmanın amacl, petrol fiyatları ile BIST 100 endeksi kapanıs fiyatları arasındaki ilişkiyi 2001:01-2020:06 dönemleri arasında aylık veriler kullanılarak analiz etmektir. Değişkenler arasındaki nedensellik ilişkisine, Balcular ve diğerleri (2010) Boostrap Rolling Window Nedensellik testi ile incelenmiştir. Elde edilen bulguda petrol fiyatlarmdan hisse senedine, hisse senedi fiyatlarından petrol fiyatlarına farklı dönemler bakımından nedenselliğin olduğu görülmektedir.

Anahtar Kelimeler: Petrol Fiyatlarl, Hisse senedi Fiyatlarl, Boostrap Rolling Window

JEL kodları: G12, E44

\begin{abstract}
There are many macroeconomic variables that affect stock prices. One of these variables is oil prices. Oil prices are not only a factor on national economies and real markets; It also affects the financial markets of countries and the stock prices traded in these markets. Accordingly, examining the relationship between oil prices and stock prices will make a positive contribution to better understanding the relationship between these factors.

The aim of this study is to analyze the relationship between oil prices and BIST 100 index closing prices by using monthly data between 2001: 01-2020: 06 periods. The causality relationship between variables was examined by Balcular et al. (2010) Boostrap Rolling Window Causality test. In the findings obtained, it is seen that there is causality in terms of different periods from oil prices to stocks, from stock prices to oil prices.
\end{abstract}

Keywords: Oil Prices, Stock Prices, Boostrap Rolling Window

JEL codes: G12, E44

\footnotetext{
${ }^{1}$ Çalışma etik kurul ve yasal izin alınması kapsamında değildir. İntihal raporu alınmıştır.
} 


\section{GíRIŞ}

Günümüzde en değerli enerji kaynaklarından biri olan petrol, dünya genelinde yaygın olarak kullanılmaktadır. Petrolün çoğu sektörde vazgeçilmez bir girdi kaynağı olması ülke ekonomilerini farklı düzeylerde petrole bağımlı kılmaktadır. Ülkeler enerji bakımından petrole bağımlı oldukları kadar petrol fiyatları da dünya ekonomik aktivitesine yön veren faktörlerden birisidir.

Ülke ekonomilerini çok yönlü etkileyen petrol fiyatları reel piyasaları etkilerken finansal piyasalara da hisse senedi fiyatları üzerinden yön vermektedir. Bu etkinin yönünü birkaç kanal yoluyla yorumlamak mümkündür. Birincisi, petrol fiyatlarındaki artış üretim maliyetlerinde artışa neden olarak nakit akışlarını ve hisse senedi fiyatlarını düşürmektedir (Jones ve Kaul, 1996). İkincisi, petrol fiyatındaki bir artış beklenen enflasyonun artmasına neden olur ve bu da para politikası kanalıyla daha yüksek faiz oranlarına yol açabilir. Dolayısıyla petrol fiyatları gelecekteki nakit akışları için kullanılan iskonto oranı yoluyla daha düşük hisse senedi fiyatlarına neden olabilmektedir (Basher vd., 2012) Rafailidis ve Katrakilidis, 2014). Üçüncüsü, petrol piyasasında ortaya çıkan şoklar (arz ve talep) hisse senedi piyasaları üzerinde farklı yönde etkiler yaratmaktadır. Küresel ekonomik büyümede meydana gelen olumlu gelişmelere bağlı olarak petrol fiyatlarının artması hisse senedi fiyatları üzerinde pozitif etki yaratırken, petrol arzında oluşan bir belirsizlik durumunda yaşanan talep şoku nedeniyle petrol fiyatlarının yükselmesi hisse senedi piyasalarını negatif yönde etkilemektedir (Kilian ve Park, 2009: 1268). Son olarak, petrol fiyatı ile hisse senedi piyasası arasındaki bağıntı, ülkelerin endüstri yapılarına, petrol ihraç/ithal etme düzeyine göre farklılık göstermektedir. Ampirik çalışmaların çoğu, pozitif petrol fiyat değişikliklerinin petrol ithalatçısı ülkeler için negatif hisse senedi fiyatlarına yol açarken petrol ihracatçısı ülkelerde petrol fiyatlarındaki artışlar hisse senedi fiyatlarını olumlu yönde etkilemektedir (Degiannakis, 2017: 6). Firmaların üretimlerinde petrole bağımlı olup olmama durumlarına göre hisse senedi fiyatları petrol fiyatı değişikliklerine heterojen tepkiler vermektedir. Üretimde girdi olarak yer alan petrol, fiyatlarının yükselmesi sonucu maliyetleri de arttıracaktır. Maliyetlerin artması nakit akışları olumsuz etkileyerek düşmesine sebep olacaktır ve dolaylı olarak hisse senedi fiyatlarının düşmesi gerçekleşecektir (Basher ve Sadorsky, 2006: 226). Genel olarak, petrol fiyatı ile hisse senedi fiyatları arasındaki ilişki karmaşık olmakla birlikte farklı kanal (lar) vasıtasıyla etkinin yönü açılanabilmektedir.

Çalışma petrol ithalatçısı konumunda olan ve petrol fiyatlarındaki değişimlere tepki veren finansal piyasalara sahip Türkiye için petrol fiyatlarının hisse senedi fiyatları üzerindeki etkisinin yönünü belirlemeyi amaçlamaktadır. Dolayısıyla petrol fiyatlarının Türkiye'de hisse senedi fiyatlarını hangi yönde etkilediğinin analiz edilmesi, yatırımcılar, politika yapıcılar ve diğer piyasa aktörleri açısından aydınlatıcı olacaktır. Ayrıca çalışmanın hem daha güncel verilerle hem de yapılan ampirik analizler bağlamında ilgili literatüre katkı sağlayacağı düşünülmektedir. Çalışmanın bundan sonraki aşamaları şu şekilde düzenlenmiştir: İkinci bölümünde bu alanda yazılmış literatür çalışmaları incelenerek özetlenmiştir. Üçüncü bölümünde çalışmada kullanılan veri seti açılanmıştır. Dördüncü bölümünde ekonometrik model ve bulgulara ilişkin bilgilere yer verilmiş ve çalışmanın son bölümünde araştırmanın sonuçlarına değinilerek önerilerde bulunulmuştur. 


\section{LITERATÜR TARAMASI}

Petrol fiyatları ile hisse senedi fiyatları ilişkisine yönelik literatürde birçok çalışma mevcuttur. Uluslararası alanda petrol fiyatlarının hisse senedi fiyatları üzerinde yarattığı etkileri hem piyasa hem de sektörel bazda araştıran çalışmalar bulunmaktadır. Özellikle son yıllarda, petrol piyasalarıyla hisse senedi piyasaları arasındaki şok ile volatilite yayılımı incelenirken, hisse senedi fiyatlarının petrol fiyatlarındaki değişime asimetrik tepki verip vermediği de araştırma konusu olmuştur. Ayrıca petrol ihraç eden ve petrol ithal eden ülkelerin de farklı yönde tepki verdiği görülmektedir. Dolayısıyla literatürde petrol fiyatlarının hisse senedi piyasası üzerine etkisini araştıran çalışmalardan elde edilen bulgular incelendiğinde ortak bir görüş olmadığı gözlemlenmiştir.

Petrol fiyatları ile hisse senedi fiyatları arasındaki ilişkiyi araştıran ilk çalışmalar Kaneko ve Lee (1995), Jones ve Kaul (1996) ve Huang ve diğerleri (1996)'ne aittir (Abdioğlu ve Değirmenci, 2014: 333). Kaneko ve Lee (1995), ABD ve Japonya için petrol fiyatları ile hisse senedi fiyatları arasındaki bağıntıyı inceledikleri çalışmalarında petrol fiyatlarındaki değişimlerin Japon hisse senedi piyasası üzerinde oldukça büyük önem arz ettiği sonucuna ulaşmışlardır. Jones ve Kaul (1996) ABD, Kanada, Japonya ve İngiltere için savaş sonrası dönemde petrol fiyatlarındaki değişimin reel hisse senedi fiyatları üzerinde olumsuz etkisi olduğu bulgusunu elde etmişlerdir. Bunun yanısıra araştırmacılar hisse senedi piyasalarının petrol fiyatlarındaki değişime duyarlı olmasının şimdiki ve gelecekteki reel nakit akımlarının değişimi ile açıklanacağını ortaya koymuşlardır. Huang vd. (1996) New York Mercantile Exchange (NYMEX)'da işlem gören günlük vadeli petrol fiyatları ile ABD günlük hisse senedi fiyatları arasındaki ilişkiyi araştırmışlardır. Araştırma sonucunda vadeli petrol fiyatlarının bazı spesifik hisse senedi fiyatlarını (Chevron, Exxon ve Mobil) açıkladığını fakat S\&P 500 gibi geniş tabanlı piyasa endeksleri üzerinde çok fazla etkiye sahip olmadığını tespit etmişlerdir.

Cong vd. (2008) Çin ekonomisini sektörel bazda ele aldıkları çalışmalarında; petrol fiyatlarında yaşanan şokların, imalat endeksi ve bazı petrol şirketleri haricinde, Çin borsa endekslerinin çoğunun reel hisse senedi fiyatları üzerinde istatistiki olarak anlamlı bir etkisi olmadığı bulgusunu elde etmişlerdir. Abdioğlu ve Değirmenci (2014), Borsa İstanbul (BİST) kapsamındaki sektörlere ilişkin hisse senedi fiyatları ile petrol fiyatları arasındaki uzun ve kısa dönemli ilişkiyi ele almışlardır. Çoğu alt sektörler için hisse senedi fiyatlarından petrol fiyatlarına doğru tek yönlü bir nedensellik olduğu tespit edilmiştir. Ferreira vd. (2020) Brezilya borsasında petrol fiyatları ile hisse senedi fiyatları arasındaki ilişkiyi sektörel bazda incelemişlerdir. Elde edilen bulguda; uzun vadede petrol fiyatının hisse senedi fiyatları üzerinde önemli bir etkisinin olmadığı fakat bu etkinin tüm sektörlerde geçerli olmayıp faaliyetlerinde petrol veya türevlerini kullanan sektörlerin petrol fiyatları ile korelasyonunun yüksek olduğu sonucuna ulaşılmıştır.

Park ve Ratti (2008) petrol fiyatı şoklarının ve volatilitesinin hisse senedi fiyatlarına olan etkisini Amerika ve 13 Avrupa ülkesi için incelemiş̧tir. Ulaşılan bulgular; petrol fiyatı şoklarının hisse senedi fiyatları üzerinde istatistiksel olarak anlamlı bir etkisinin olduğu yönündedir. Wang vd. (2013) petrol fiyatı şokları ile hisse senedi piyasaları arasındaki bağıntıyı petrol ihracatı/ ithalatı yapan ülkeler için incelemişlerdir. Ulaşılan sonuçlar; bir ülkedeki petrol fiyatı şoklarına hisse senedi fiyatlarının verdiği tepkinin büyüklügünün, süresinin ve hatta yönünün büyük ölçüde ülkenin dünya petrol piyasasında ithalatçı veya 
ihracatçı konumda olması ve fiyat şokunun talepten/ arzdan kaynaklanıyor olması durumuna göre farklılık göstereceği yönündedir. Buna göre, hem kısa hem de uzun vadede petrol fiyat şoklarının hisse senedi fiyatları üzerindeki açıklayıcı etkisinin petrol ihraç eden ülkelerin petrol ithal eden ülkelere göre çok daha güçlü olduğu gösterilmiştir. Çalışmada petrol fiyatlarındaki belirsizliğin hisse senedi fiyatları üzerindeki etkisi de incelenmiştir. Sonuçta petrol arzındaki belirsizliğin hem petrol ithal eden hem de petrol ihraç eden ülkelerdeki borsaları negatif yönde etkilediği tespit edilmiştir. Petrol talebi belirsizliğinin ise petrol ihraç eden ülke borsaları üzerinde etkisinin önemli olduğu fakat petrol ithal eden ülke borsaları üzerinde etkisinin geçici olduğu sonucuna ulaşılmıştır. Hamdi vd. (2019) sektörel bazda petrol fiyatı volatilitesinin hisse senedi fiyatları üzerindeki etkisini petrol ihraç eden ülkeler (Körfez İşbirliği Konseyi Ülkeleri) için incelemişlerdir. Ulaşılan sonuçlar enerji ve ulaştırma sektörleri dışındaki tüm sektörlerin, petrol fiyatı volatilitesinden etkilendiğini göstermektedir.

Ramos ve Veiga (2013) petrol fiyat değişikliklerinin hisse senedi fiyatları üzerinde asimetrik etkiler yaratıp yaratmadığını, petrol ithal/ihraç eden ülkeler için araştırmışlardır. Araştırma sonucunda petrol fiyatlarındaki artışlar, petrol ithal eden ülkelerin hisse senedi fiyatlarını negatif yönde etkilerken, petrol ihraç eden ülkeler için bu etkinin pozitif yönde olduğu tespit edilmiştir. Akyol vd. (2019) Türkiye'de petrol fiyatlarının hisse senedi fiyatları üzerindeki asimetrik etkisini inceledikleri çalışmalarında uzun dönemde petrol fiyatlarının düşmesinin BIST-100 endeks getirileri üzerinde negatif yönlü etkisinin olduğu sonucuna ulaşmışlardır. Aksine petrol fiyatlarındaki pozitif yönlü değişimlerin BIST-100 endeks getirileri üzerinde anlamlı herhangi bir etkisi olmadığı görülmüştür.

Literatürde petrol fiyatlarının hisse senedi fiyatları üzerindeki etkisini inceleyen çalışmalardan elde edilen ampirik bulgulara ilişkin bilgiler Tablo 1 'de özetlenmektedir.

Tablo 1: Petrol Fiyatlarının Hisse Senedi Fiyatları Üzerindeki Etkisini İnceleyen Çalışmalar

\begin{tabular}{|c|c|c|c|c|}
\hline Yazar(lar) & Yöntem & Dönem & Ülke(ler) & Özet Sonuç \\
\hline $\begin{array}{l}\text { Filis } \\
(2010)\end{array}$ & VAR Analizi & $\begin{array}{l}1996: 1 \\
2008: 6\end{array}$ & Yunanistan & $\begin{array}{l}\text { Petrol fiyatlarının hisse senedi fiyatları üzerinde } \\
\text { negatif yönlü etkisi var. }\end{array}$ \\
\hline $\begin{array}{l}\text { İşcan } \\
(2010)\end{array}$ & $\begin{array}{l}\text { VAR Granger } \\
\text { Nedensellik } \\
\text { Analizi }\end{array}$ & $\begin{array}{l}2001: 12 \\
2009: 12\end{array}$ & Türkiye & $\begin{array}{l}\text { Petrol fiyatları ile hisse senedi fiyatları arasında } \\
\text { nedensellik ilişkisi bulunmamaktadır. }\end{array}$ \\
\hline $\begin{array}{l}\text { Güler ve } \\
\text { Nalın } \\
(2013)\end{array}$ & $\begin{array}{l}\text { Granger } \\
\text { Nedensellik } \\
\text { Analizi }\end{array}$ & $\begin{array}{l}\text { 1997:02 } \\
\text { 2012:11 }\end{array}$ & Türkiye & $\begin{array}{l}\text { Seriler uzun dönemde birlikte hareket etmelerine } \\
\text { rağmen kısa dönemde ham petrol fiyatlarındaki } \\
\text { bir değişim hisse senedi fiyatları üzerinde bir } \\
\text { nedensellik oluşturmamaktadır. }\end{array}$ \\
\hline $\begin{array}{l}\text { Şener vd. } \\
\text { (2013) }\end{array}$ & $\begin{array}{c}\text { Hatemi-j- } \\
\text { Irandoust } \\
\text { Eşbütünleşme } \\
\text { Testi }\end{array}$ & 2002-2012 & Türkiye & $\begin{array}{l}\text { Petrol fiyatlarındaki değişim hisse senetleri } \\
\text { fiyatlarını etkilemektedir. }\end{array}$ \\
\hline $\begin{array}{l}\text { Dhaoui ve } \\
\text { Khraief } \\
(2014)\end{array}$ & EGARCH & $\begin{array}{l}1991: 1 \\
2013: 9\end{array}$ & $\begin{array}{l}8 \text { Gelişmiş } \\
\text { Ülke }\end{array}$ & $\begin{array}{l}\text { Seçilen ülkelerin yedisinde petrol fiyatları ile } \\
\text { hisse senedi fiyatları arasında negatif korelasyon } \\
\text { olduğu gözlemlenmiştir. }\end{array}$ \\
\hline $\begin{array}{c}\text { Avc1 } \\
(2015)\end{array}$ & $\begin{array}{l}\text { Granger } \\
\text { Nedensellik } \\
\text { Analizi }\end{array}$ & $\begin{array}{l}\text { 2003:01 } \\
\text { 2013:12 }\end{array}$ & Türkiye & $\begin{array}{l}\text { Petrol fiyatları ile hisse senedi fiyatları arasında } \\
\text { uzun dönemli bir ilişki tespit edilmiştir. } \\
\text { Nerdensellik analizine göre petrol fiyatlarından } \\
\text { hisse senedi fiyatlarına doğru tek yönlü bir ilişki } \\
\text { vardır. }\end{array}$ \\
\hline
\end{tabular}




\begin{tabular}{|c|c|c|c|c|}
\hline $\begin{array}{l}\text { Şahin } \\
\text { (2015) }\end{array}$ & $\begin{array}{l}\text { Toda } \\
\text { Yamamoto ve } \\
\text { Etki-Tepki } \\
\text { Analizi }\end{array}$ & $\begin{array}{l}\text { 2001:01 } \\
\text { 2013:10 }\end{array}$ & Türkiye & $\begin{array}{l}\text { Petrol fiyatları uzun vadede BIST 100, BIST } \\
\text { İmalat ve BIST Teknoloji endekslerinin tahminini } \\
\text { iyileştirmektedir. Ancak kisa vadede petrol } \\
\text { fiyatlarının bu borsa göstergeleri üzerinde bir } \\
\text { etkisi yoktur. }\end{array}$ \\
\hline $\begin{array}{l}\text { Alqattan ve } \\
\text { Alhayky } \\
\text { (2016) }\end{array}$ & $\begin{array}{l}\text { ARDL } \\
\text { ECM }\end{array}$ & $\begin{array}{l}\text { 2015:02 } \\
2016: 11\end{array}$ & KİK & $\begin{array}{l}\text { Umman dışında diğer tüm Körfez İşbirliği } \\
\text { Konseyi (KİK) ülkelerinin petrol fiyatları ile } \\
\text { hisse senedi piyasaları arasında uzun dönemde } \\
\text { eşbütünleşme ilişkisi yoktur. Kısa vadede ise bir } \\
\text { ilişki vardır. }\end{array}$ \\
\hline $\begin{array}{l}\text { Büberkökü } \\
\text { (2017) }\end{array}$ & $\begin{array}{l}\text { Toda- } \\
\text { Yamamoto } \\
\text { Nedensellik } \\
\text { Analizi } \\
\end{array}$ & $\begin{array}{l}\text { 1999:01 } \\
\text { 2014:09 }\end{array}$ & Türkiye & $\begin{array}{l}\text { Petrol fiyatlarıyla hisse senedi piyasaları arasında } \\
\text { tek tip bir nedensellik ilişkisi yoktur. }\end{array}$ \\
\hline $\begin{array}{l}\text { Akyol ve } \\
\text { Baltaci } \\
(2018)\end{array}$ & ARDL & $\begin{array}{l}\text { 2006:01 } \\
\text { 2015:09 }\end{array}$ & Türkiye & $\begin{array}{l}\text { Uzun dönemde petrol fiyatlarının hisse senedi } \\
\text { fiyatları üzerinde negatif yönlü ve anlamlı etkisi } \\
\text { vardır. }\end{array}$ \\
\hline $\begin{array}{l}\text { Cheik vd. } \\
\text { (2018) }\end{array}$ & STR & $\begin{array}{l}\text { 2004:01 } \\
2015: 12\end{array}$ & KİK & $\begin{array}{l}\text { KİK ülkelerinde hisse senedi fiyatları petrol } \\
\text { fiyatlarındaki değişime heterojen tepki } \\
\text { vermektedir. }\end{array}$ \\
\hline $\begin{array}{l}\text { Karhan ve } \\
\text { Aydın } \\
\text { (2018) }\end{array}$ & $\begin{array}{l}\text { Frekans } \\
\text { Dağılımı ve } \\
\text { Hatemi J } \\
\text { Nedensellik } \\
\text { analizi }\end{array}$ & 2009-2018 & Türkiye & $\begin{array}{l}\text { Uzun dönemde petrol fiyatları ve hisse senedi } \\
\text { piyasaları arasında nedensellik yoktur. }\end{array}$ \\
\hline $\begin{array}{l}\text { Syzdykova } \\
\text { (2018) }\end{array}$ & $\begin{array}{l}\text { Panel } \\
\text { Regresyon } \\
\text { Analizi }\end{array}$ & $2000-2016$ & $\begin{array}{l}\text { BRIC } \\
\text { Ülkeleri }\end{array}$ & $\begin{array}{l}\text { Petrol fiyat değişimleri hisse senedi fiyatları } \\
\text { üzerinde anlamlı ve negatif etkiye sahiptir. }\end{array}$ \\
\hline $\begin{array}{l}\text { Kelikume ve } \\
\text { Muritala } \\
\text { (2019) }\end{array}$ & $\begin{array}{l}\text { OLS } \\
\text { DOLS }\end{array}$ & $\begin{array}{l}2010: 1 Q \\
2018: 4 Q\end{array}$ & $\begin{array}{l}5 \text { Afrika } \\
\text { Ülkesi }\end{array}$ & $\begin{array}{l}\text { Analiz sonucu; petrol ihraç eden } 5 \text { Afrika } \\
\text { ülkesinde petrol fiyatlarının hisse senedi fiyatları } \\
\text { üzerindeki etkisinin önemli olmadığını } \\
\text { göstermektedir. }\end{array}$ \\
\hline $\begin{array}{l}\text { Shabbir vd. } \\
\qquad \text { (2019) }\end{array}$ & ARDL & $1985-2016$ & Pakistan & $\begin{array}{l}\text { Petrol fiyatlarındaki artış faaliyetlerinde petrol } \\
\text { tüketen firmaların hisse senedi fiyatlarının } \\
\text { düşmesine yol açmaktadır. }\end{array}$ \\
\hline
\end{tabular}

\section{VERİ ve MODEL}

Çalışmada 2001:01-2020:06 dönemleri arasında aylık veriler kullanılarak Türkiye'de petrol fiyatları ve hisse senedi fiyatları arasındaki nedensellik ilişkisi incelenmiştir. Çalışmada kullanılan değişsenler; Türkiye Cumhuriyeti Merkez Bankası internet sitesinden EVDS veri tabanından elde edilen BIST-100 kapanış fiyatları ve petrol piyasasında temel ölçüt olarak kullanılan Avrupa Brent ham petrol fiyatlarından oluşmaktadır. Uluslararası Enerji Ajansından (IEA) alınan ham petrol fiyatları verileri varil başına dolar cinsinden hesaplanmaktadır. Değişkenlere ait açıklamlar Tablo 2' de yer almaktadır.

Petrol fiyatları ve hisse senedi fiyatları arasındaki ilişkinin literatürde yer alan çalışmalara dayanarak ve petrol fiyatlarının ülke ekonomilerini hem reel hem de finansal piyasalardaki akışı etkilemesinden dolayı bir nedensellik ilişkisi içinde olması ve analiz sonucunun bu hipotezi desteklemesi beklenmektedir. 
Tablo 2: Değişkenlerin Açıklaması

\begin{tabular}{llll}
\hline Değişken Simgesi & Açılaması & Kaynağı & Dönemi \\
\hline Inpf & Petrol fiyatları & IEA (Uluslararası & 2001:01-2020:06 \\
& & Enerji Ajansı) & \\
\hline Inhsp & Hisse senedi fiyatları & EVDS (Elektronik Veri & 2001:01-2020:06 \\
& & Dağıtım Sistemi) & \\
& &
\end{tabular}

\section{YÖNTEM ve BULGULAR}

\subsection{Balcılar ve Diğerleri (2010) Bootstrap Rolling Window Nedensellik Testi}

Balcılar vd. (2010) yılındaki çalışmasında LR (corrected likelihood ratio) nedensellik testini "residual-based bootstrap" yöntemi kullanarak uygulamıştır. Boostrap sürecine dayalı LR Granger nedensellik test süreci iki değişkenli VAR(p) modelini $t=1,2, \ldots, T$ olmak üzere (Şahin ve Durmuş, 2019);

$$
y_{t}=\Phi_{0}+\Phi_{1} y_{t-1}+\ldots+\Phi_{p} y_{t-p}+\varepsilon_{t}
$$

$y_{t}=\left[y_{1 t}, y_{2 t}\right]_{2 x 1}$ matris olmak üzere $\operatorname{VAR}(\mathrm{p})$ modelini;

$$
\left(\begin{array}{l}
y_{1 t} \\
y_{2 t}
\end{array}\right)=\left(\begin{array}{l}
\phi_{10} \\
\phi_{20}
\end{array}\right)+\left(\begin{array}{ll}
\phi_{11}(L) & \phi_{12}(L) \\
\phi_{21}(L) & \phi_{22}(L)
\end{array}\right)\left(\begin{array}{l}
y_{1 t} \\
y_{2 t}
\end{array}\right)+\left(\begin{array}{l}
\varepsilon_{1 t} \\
\varepsilon_{2 t}
\end{array}\right)
$$

İfadesinde $\emptyset_{i j}^{(L)}=\sum_{k=1}^{p} \emptyset_{i j}, k^{L^{k}}$ i,j=1,2 ve gecikme operatörü $L_{x_{t}}^{k}=x_{t-k}$ şeklindedir. Testin sıfır hipotezi $\emptyset_{12, i}=0$ olmak üzere $y_{2 t}, y_{1 t}$ 'nin Granger nedeni değildir şeklinde ifade edilmektedir. Aşağıda Balcılar vd., (2010) Boostrap Rolling Window nedensellik testi sonuçları Şekil 1 ve Şekil 2' de gösterilmektedir.

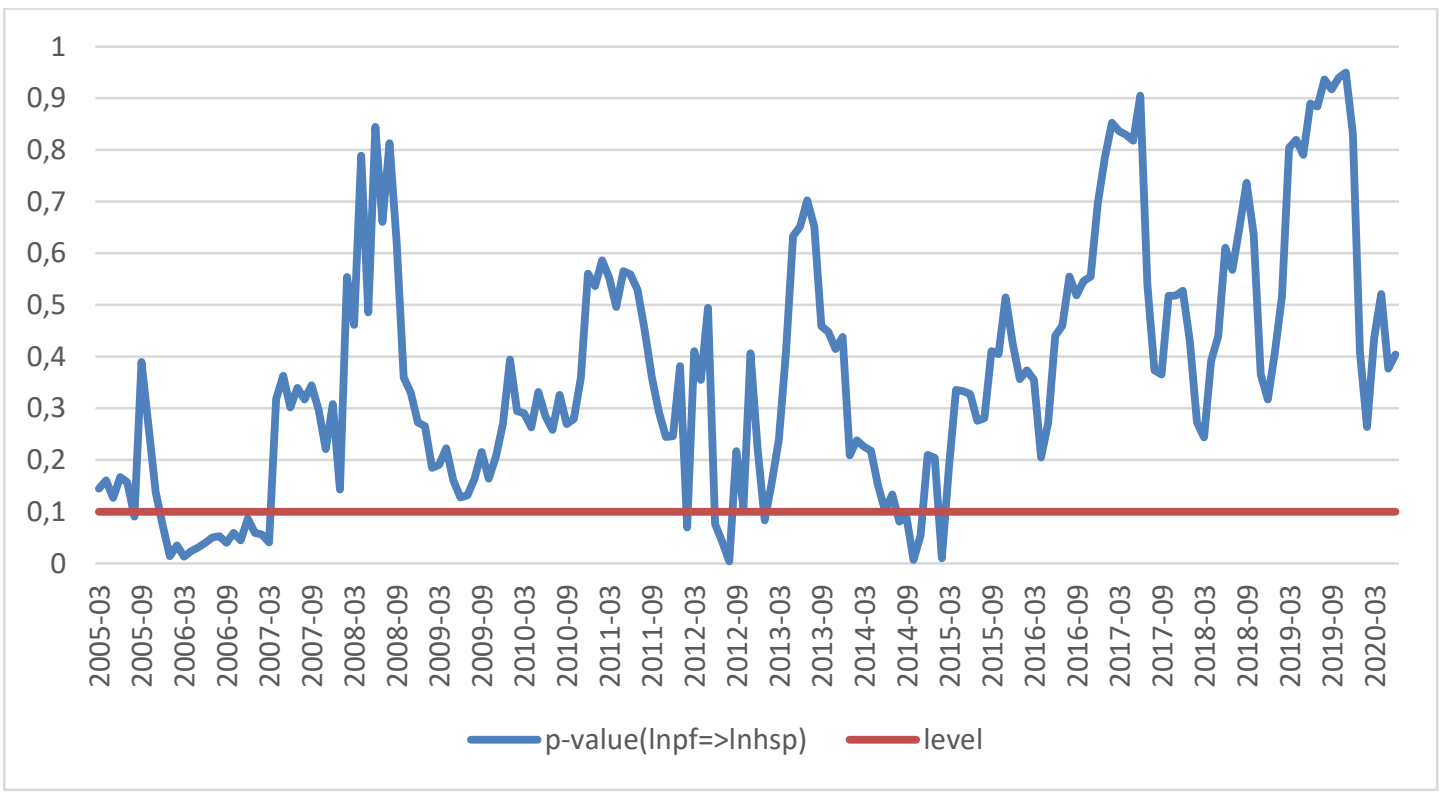


Şekil 1: Balc1lar Boostrap Rolling Window Nedensellik Testi

Şekil 1'e göre; 2005 Ağustos ve Aralık aylarında; 2006 Ocak, Şubat, Mart, Nisan, Mayıs, Haziran, Temmuz, Ağustos, Eylül, Ekim, Kasım, Aralık; 2007 Ocak, Şubat ve Mart; 2012 Şubat, Haziran, Temmuz ve Ağustos; 2013 Ocak; 2014 Ağustos, Eylül, Ekim ve Kasım; 2015 Şubat aylarında petrol fiyatlarından hisse senedi fiyatlarına doğru nedensellik ilişkisinin olduğu görülmektedir.

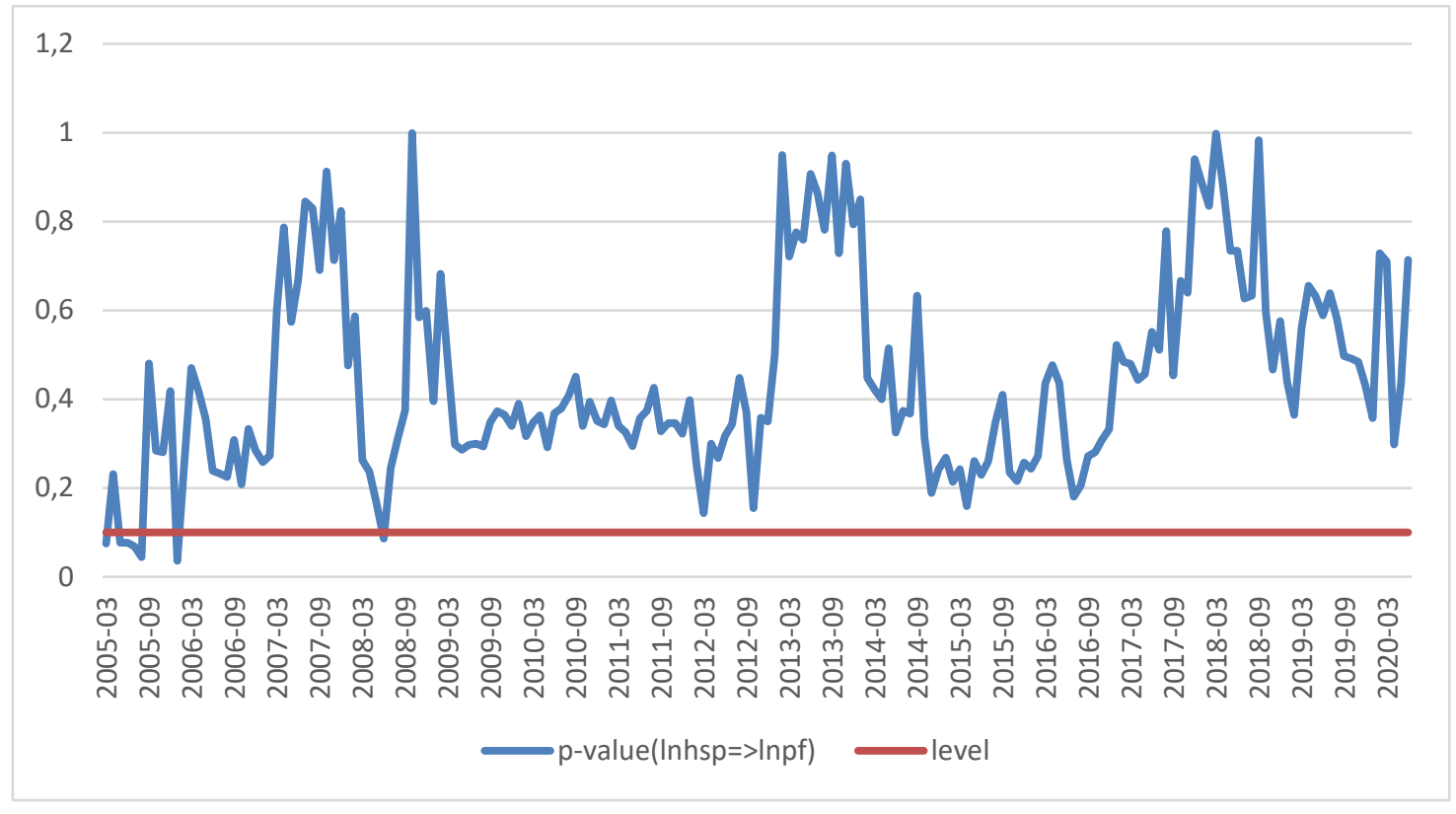

Şekil 2: Balcılar Boostrap Rolling Window Nedensellik Testi

Şekil 2'ye göre; 2005 Mart, Mayıs, Haziran, Temmuz, Ağustos; 2006 Ocak; 2008 Haziran aylarında hisse senedi fiyatlarından petrol fiyatlarına doğru nedensellik ilişkisinin olduğu görülmektedir.

\section{SONUÇ}

Çoğu sektörde vazgeçilmez bir girdi kaynağı olan petrol ülke ekonomileri için büyük önem arz etmektedir. Ülkeler enerji bakımından petrole bağımlı oldukları için enerji fiyatlarının önemli bir belirleyicisi olan petrol fiyatları da dünya ekonomisini yönlendirici ekonomik faktörlerden birisi olmaktadır. Bunun yanısıra petrol fiyatları ülkelerin finansal piyasalarını ve bu piyasalarda işlem gören hisse senedi fiyatlarını da etkilemektedir. Petrol fiyatlarındaki değişimler, ekonomilerde belirsizlik ve risk ortamı oluşmasına sebep olabilirken finansal piyasalarda hem yatırım aracı olarak hem de hisse senedi piyasasını etkileyen bir faktör olarak finansal piyasaları da yakında ilgilendirmektedir. Bu bağlamda çalışmada petrol ithalatçısı konumunda olan Türkiye için petrol fiyatları ile BIST 100 endeksi kapanış fiyatları arasındaki ilişki 2001:01 ve 2020:6 dönemine ait aylık veriler kullanılarak, petrol fiyatlarının Borsa İstanbul' da işlem gören piyasa değeri ve işlem hacmi en yüksek 100 işletmenin hisse senetleri ile olan ilişkisi Rolling Windows nedensellik testi ile incelenmiştir.

Değişkenler arasındaki nedensellik ilişkisine Balcılar vd. (2010) Boostrap Rolling Window nedensellik testi ile bakılmıştır. Balcılar vd.(2010) Boostrap Rolling Window nedensellik testinde petrol fiyatlarından hisse senedine (2005, 2006, 2007, 2012, 2013, 2015); hisse senedi 
fiyatlarından petrol fiyatlarına $(2005,2006,2008)$ farklı dönemler bakımından nedenselliğin olduğu görülmektedir.

Analiz kapsamında uygulanan nedensellik testi sonuçları, petrol fiyatları ve BIST 100 endeksi arasında farklı dönemlerde nedensellik olduğuna işaret etmektedir. Petrol fiyatlarında değişimler hisse senetleri fiyatları üzerinde etken olacağı genel olarak beklenen bir durumdur. Fakat hisse senedi fiyatlarının petrol fiyatları üzerinde etki göstermesi uluslararası yatırımcıların Türkiye' de hisse senedi piyasalarındaki pozisyonlarını değiştirerek petrol gibi alternatif yatırım araçlarına yönelmiş olabileceğini muhtemel kılmaktadır.

Petrol fiyatları ile hisse senedi fiyatları arasındaki nedensellik sonucuna göre; hisse senedi piyasasındaki yatırımcıların yatırım öncesinde petrol fiyatlarındaki artış/azalışları gözlemlemlerken, petrol piyasasındaki yatırımcıların da hisse senedi fiyatlarındaki değişimleri dikkate almaları yararlı olacaktır.

\section{KAYNAKÇA}

Abdioğlu, Z. ve Değirmenci, N. (2014). Petrol Fiyatları- Hisse Senedi Fiyatları İlişkisi: BİST Sektörel Analiz. Kafkas Üniversitesi İktisadi ve İdari Bilimler Fakültesi Dergisi, 5 (8), $1-24$.

Akyol, H., Karakuş, K. ve Ağırkaya, M. B. (2019). Petrol Fiyatları ve Hisse Senedi Getirileri Arasındaki Asimetrik İlişki: Türkiye Örneği. Uluslararası Sosyal Bilimler Kongresi, 79 Kasim, 700-710.

Alqattan, A. A. ve Alhayky, A. (2016). Impact of Oil Prices on Stock Markets: Evidence from Gulf Cooperation Council (GCC) Financial Markets. Amity Journal of Finance, 1 (1), 18.

Avcı, Ö. B. (2015). Petrol Fiyatlarının Hisse Senedi Piyasasına Etkisi. Adnan Menderes Üniversitesi Sosyal Bilimler Enstitüsü Dergisi, 2 (3), 27-34.

Balcılar, M., Özdemir, Z. ve Arslantürk, Y.(2010). Economic Growth and Energy Consumption Causal Nexus Viewed Through a Boostrap Rolling Window. Energy Economics, 32: 1398- 1410.

Basher, S.A., Haug, A. ve Sadorsky, P. (2012). Oil price, exchange rates and emerging stock markets. Energy Economics, 34 (1), 227-240.

Basher, S.A. ve Sadorsky, P. (2006). Oil price risk and emerging stock markets. Global Finance Journal. 17 (2), 224-251.

Büberkökü, Ö. (2017). Çoklu Yapısal Kırılmalar Altında Petrol Fiyatlarının Türk Hisse Senedi Piyasaları Üzerindeki Etkisinin İncelenmesi. Bankacılık ve Sermaye Piyasası Araştırmaları Dergisi, 1 (2), 15-32.

Cheikh, N. B., Naceur, S. B., Kanaan, O. ve Rault, C. (2018). Oil Prices and GCC Stock Markets: New Evidence from Smooth Transition Models. IMF Working Paper 18/98, Washington: International Monetary Fund.

Cong, R.-G., Wei, Y.-M., Jiao, J.-L. ve Fan, Y. (2008). Relationships between oil price shocks and stock market: An empirical analysis from China. Energy Policy, 36, 3544-3553. 
Degiannakis, S., Filis G. ve Arora V. (2017). Oil Prices and Stock Markets. Working Paper Series, U.S. Energy Information Administration Washington, DC 20585.

Dhaoui, A. ve Khraief, N. (2014). Empirical Linkage between Oil Price and Stock Market Returns and Volatility: Evidence from International Developed Markets. Discussion Paper, http://www.economics-ejournal.org/economics/discussionpapers/2014-12, (Erişim Tarihi: 25.07.2020).

Ferreira, P., Pereira, E. ve Silva, M. (2020). The relationship between oil prices and the Brazilian stock market. Physica A: Statistical Mechanics and its Applications, 545, 123745.

Filis, G. (2010). Macro economy, stock market and oil prices: Do meaningful relationships exist among their cyclical fluctuations?. Energy Economics, 32, 877-886.

Güler, S. ve Nalın, H. T. (2013). Petrol Fiyatlarının İMKB Endeksleri Üzerindeki Etkisi. Ekonomik ve Sosyal Araştırmalar Dergisi, 9 (2), 79-97.

Hamdi, B., Aloui, M., Alqahtani , F. ve Tiwari, A. (2019). Relationship between the oil price volatility and sectoral stockmarkets in oil-exporting economies: Evidence from wavelet nonlinear denoised based quantile and Granger-causality analysis. Energy Economics, $80,536-552$.

Huang, R.D., Masulis, R.W. ve Stoll, H.R. (1996). Energy Shocks and Financial Markets. The Journal of Future Markets. 16, 1-25.

IEA-International Energy Agency (2020). https://www.iea.org/statistics/oil/, (Erişim Tarihi: 10.10.2020).

İşcan, E. (2010). Petrol Fiyatının Hisse Senedi Piyasası Üzerindeki Etkisi. Maliye Dergisi, 158, 607-617.

Jones, C.M. ve Kaul, F. (1996). Oil and the Stock Markets. The Journal of Finance. 51 (2) , 463491.

Kaneko, T. ve Lee, B.S. (1995). Relative Importance of Economic Factors in The U.S. and Japanese Stock Markets. Journal of The Japanese and International Economies. 9 (3), 290-307.

Karhan, G. ve Aydın, H. İ. (2018). Petrol Fiyatları, Kur ve Hisse Senedi Getirileri Üzerine Bir Araştırma. Akademik Araştırmalar ve Çalışmalar Dergisi, 10 (9), 405-413.

Kelikume, I. ve Muritala, O. (2019). The Impact of Changes in Oil Price on Stock Market: Evidence from Africa. International Journal of Management, Economics and Social Sciences, 8 (3), 169-194.

Kilian, L., Park, C. (2009). The impact of oil price shocks on the U.S. stock market. International Economics Review, 50 (4), 1267-1287.

Park, J. ve Ratti, R. A. (2008). Oil Price Shocks and Stock Markets in The U.S. and 13 European Countries. Energy Economics, 30 (5), 2587-2608.

Rafailidis, P. ve Katrakilidis, C. (2014). The relationship between oil price and stock prices: a nonlinear asymmetric cointegration approach. Applied Financial Economics, 24 (12), 793-800. 
Ramos, S. b. ve Veiga, H. (2013). Oil price asymmetric effects: Answering the puzzle in international stock markets. Energy Economics, 38, 136-145.

Shabbir, A., Kousar, S. ve Batool, S. A. (2019). Impact of Gold and Oil Prices an the Stock Market in Pakistan. Journal of Economics, Finance and Administrative Science, 1-16.

Syzdykova, A. (2019). Petrol Fiyatlarının BRIC Ülkelerinin Borsalarına Etkisi. Uluslararası Ekonomi, İşletme ve Politika Dergisi, 2 (1), 1-20.

Şahin, D. ve Durmuş, S. (2019). Türkiye'de Reel Efektif Döviz Kuru, İhracat ve İthalat Arasındaki Nedensellik İlişkisinin Analizi. Karabaük Üniversitesi Sosyal Bilimler Enstitüsü Dergisi, 9(1).

Şahin, S. (2015). Crude Oıl and Stock Market Prıces: Evıdence from an Emerging Market. Çukurova Üniversitesi Sosyal Bilimler Enstitüsü Dergisi, 24 (1), 61-70.

Şener, S., Yılancı, V. ve Tıraşoğlu, M. (2013), Petrol Fiyatları İle Borsa İstanbul'un Kapanış Fiyatları Arasındaki Saklı İlişkinin Analizi. Selçuk Üniversitesi İ̈BF Sosyal ve Ekonomik Araştırmalar Dergisi, 26, 231-248.

TCMB (2020). http://www.tcmb.gov.tr/ (Erişim Tarihi: 10.10.2020).

Wang, Y.,Wu, C., ve Yang, L. (2013). Oil price shocks and stock market activities: Evidence from oil-importing and oil-exporting countries. Journal of Comparative Economics, 41 (4), 1220-1239. 